\title{
Design and Development of Information System of Population and Civil Registration Office of Malang Regency Based on Android
}

\author{
Farid Wahyudia, 1, *, Listanto Tri Utomo ${ }^{\text {b, } 2}$ \\ a Information System Study Program, Faculty of Science and Technology, Raden Rahmat Islamic University of Malang, \\ Indonesia \\ b Informatics Engineering Study Program, Faculty of Science and Technology, Raden Rahmat Islamic University of \\ Malang, Indonesia \\ 1 faridstifler@gmail.com; ${ }^{2}$ listantotri@gmail.com \\ * corresponding author
}

\section{ABSTRACT}

Keywords Information Systems Android
In the service in the population and civil registration services of Malang Regency, there are still many problems that are often faced by employees and the community. Among them is the lack of information about the requirements in taking care of population administration and civil records so that there are still many people who have to return to complete the required requirements or a long queue due to an error in writing the name, date of birth and so forth. The application developed in this research is based on Android. With the support of the development of the operating system on mobile, especially Android, problems faced by the community can be overcome. The people of Malang Regency are no longer confused about finding information about the requirements to take care of population administration at the Malang Regency Population and Civil Registry Office.

\section{Introduction}

In the service in the population and civil registration services of Malang Regency there are still many problems that are often faced by employees and the community. Among them is the lack of information regarding the requirements in taking care of population administration and civil registration so that there are still many people who have to return to complete the required requirements or the occurrence of long queues due to incorrect writing of names[1], places of birth dates and so forth. Therefore the author took the initiative to make an application of population information and civil registration to facilitate the community in taking care of population administration and civil registration in Malang regency.

With the support of the development of the operating system on mobile, especially Android, problems faced by the community can be overcome[2][3]. The people of Malang Regency are no longer confused about finding information about the requirements to take care of population administration in the Malang Regency Population and Civil Registry Service, simply by opening the cell phone the community can already know the requirements to take care of the population administration.

\section{The Proposed Method}

\subsection{Definition of Information Systems}

A unit of procedures or components that are interrelated with one another, work together by the rules applied to form a common goal, wherein a system if there is only one part that is not working or damaged, then a goal can be the result of errors or the output. The system is a collection of interrelated elements that are responsible for processing input to produce [4].

105 | P a g e 
Information is the result of processing data into a form that is more useful for recipients who describe real events to be used in decision making [5].

\section{Method}

The application development model used in this study uses the Waterfall model as shown in Figure 1. [6].

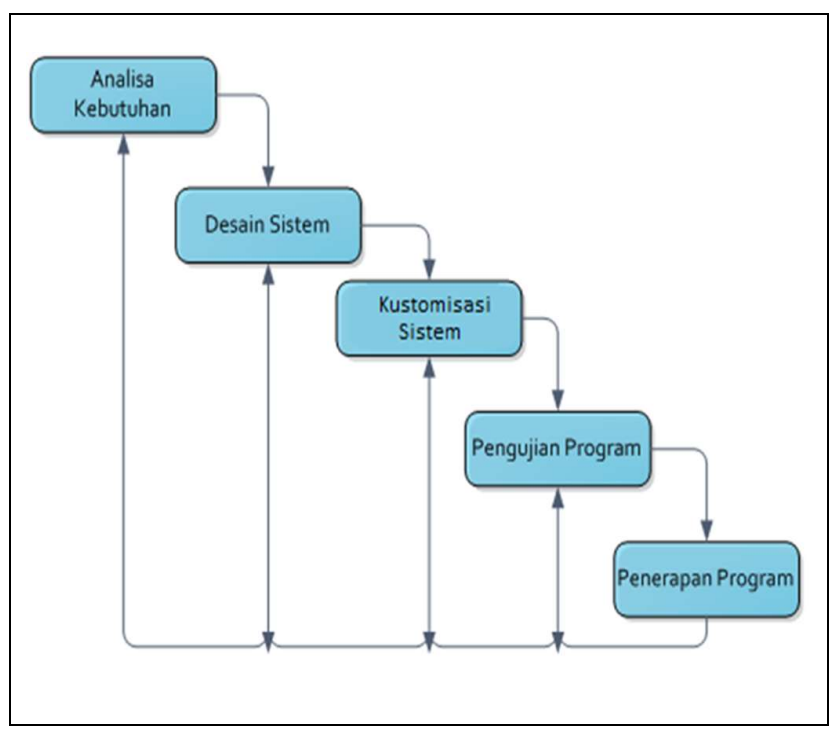

Fig. 1. Waterfall Model

Research Steps:

a. Needs Analysis

At this stage the user and the developer (researcher) together define the format of the software as a whole, identify all the requirements for the features, and outline of the system to be made.

b. System Design

The design is the stage of preparation of the most optimal process, data, process flow, and data relationship to run the application process and meet user needs by the results of the needs analysis. The documentation generated from the design stage of this system includes : Use Case Diagrams, Activity Diagrams, Sequence Diagrams, and Class Diagrams.

\section{c. Program Customization}

Customizing the program code is the stage of translating the system design into the program by adjusting the menus or features of the decision support system. At this stage, a menu or feature on the decision support system will be generated that will suit the user's needs.

\section{d. System Testing}

At this stage, all input and output processes are tested so that the possibility of errors and bugs can be immediately identified and improvements made in writing the program code.

e. System Implementation

After the user states that the system is in accordance with expectations and needs, the system is ready to be implemented 


\section{Results and Discussion}

\subsection{Analysis of System Requirements}

In analyzing the information media used, the writer analyzes it directly. The author analyzes the official website of the Malang Regency Population and Civil Registry Office and uses APP Inventor 2 for making android-based applications.

\subsection{System Design}

\subsubsection{Flowchart}

Following is the flowchart for the Capil Dispenduk program. Figure 2 show capillary dispatch application flowchart

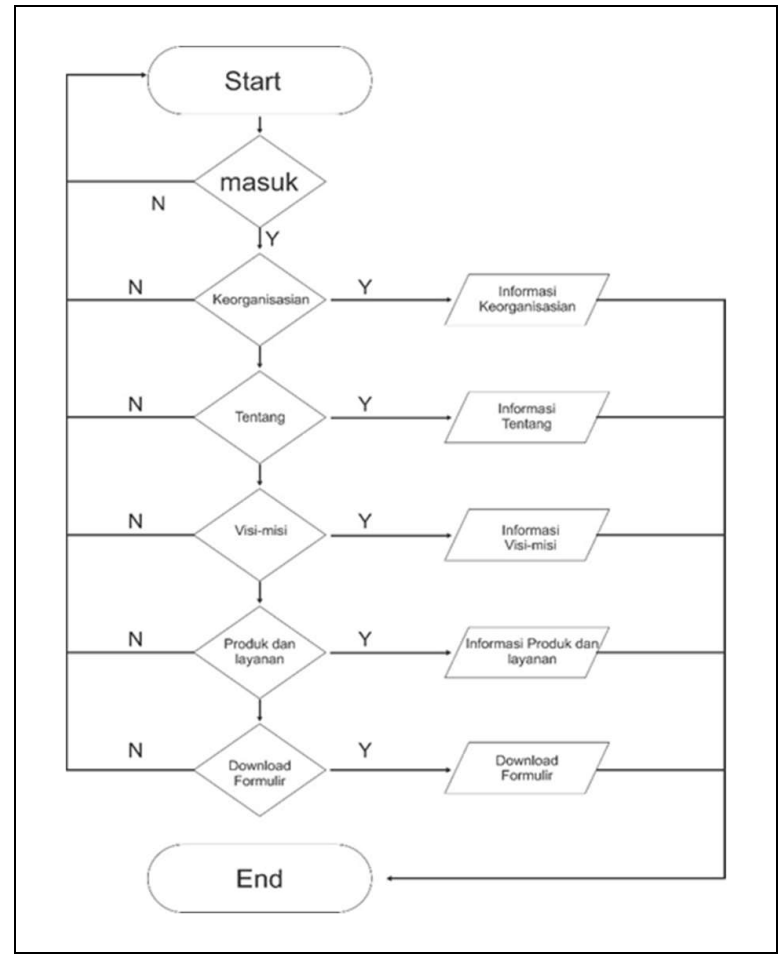

Fig. 2. Capillary Dispatch Application Flowchart

\subsubsection{Use Case Diagram}

The use case diagram in Figure 3 is a use case diagram created from the user's perspective. In this application, the user can perform 4 interactions including access to the main page, access the content menu, access content, and access the menu about the application.

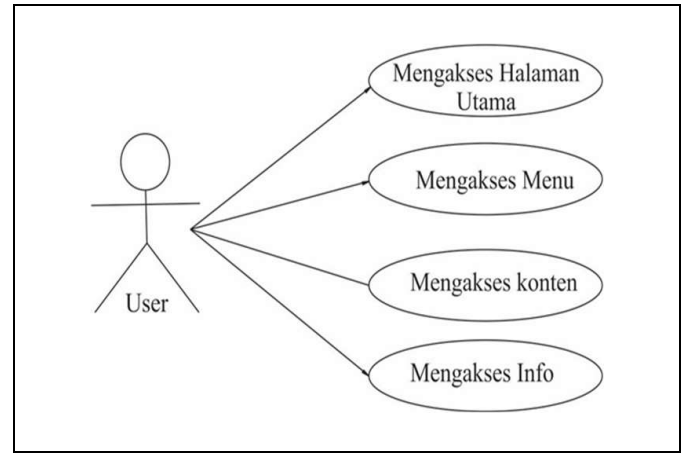

Fig. 3. Usecase diagram of Capil Reservoir Application

107 I P a g e 


\subsubsection{DFD Level 0}

Level 0 diagram is a general description of a data flow that connects the processes that occur in the Capil Dispenduk application. Following DFD Level 0 on Capil Dispenduk application. Figure 4

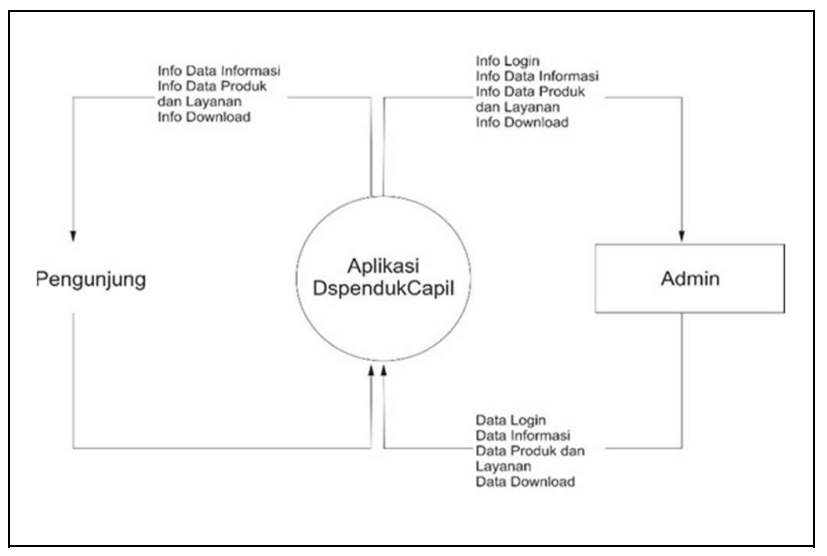

Fig. 4. DFD Level 0 Application Capil Reservoir

\subsubsection{DFD Level 1}

DFD sketch for overview with (level 1) based on the process in a tiered chart. Following DFD Level 1 in the Capil Dispenduk application. Figure 5

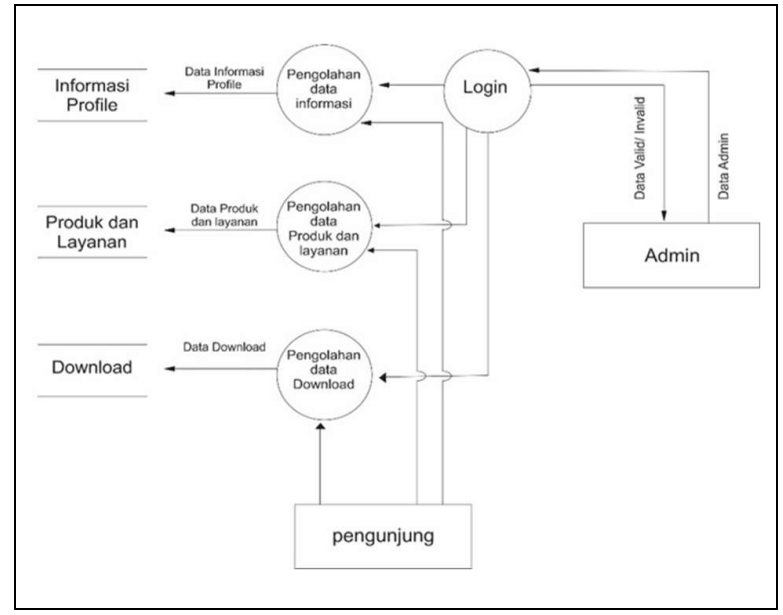

Fig. 5. DFD Level 1 Application Capil Reservoir

\subsubsection{Design Sketch App Display}

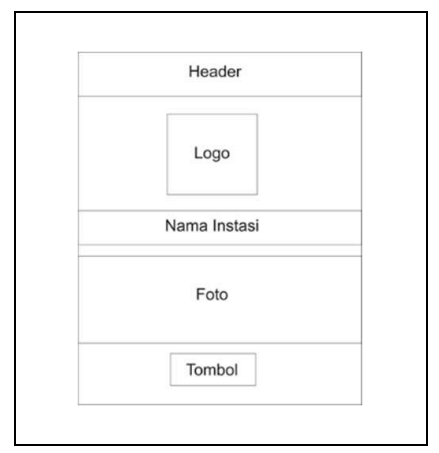

Fig. 6. Initial Application / Home Interface

108 I P a g e 
Component Figure 6:

a. Header = "DispendukCapil App"

b. The logo = Malang Regency Logo

c. Instasi Name $=$

d. Photo =

e. Button =
"Malang Regency Population and Civil Registry Office

Photograph of the residence office and civil registry

Button to the menu

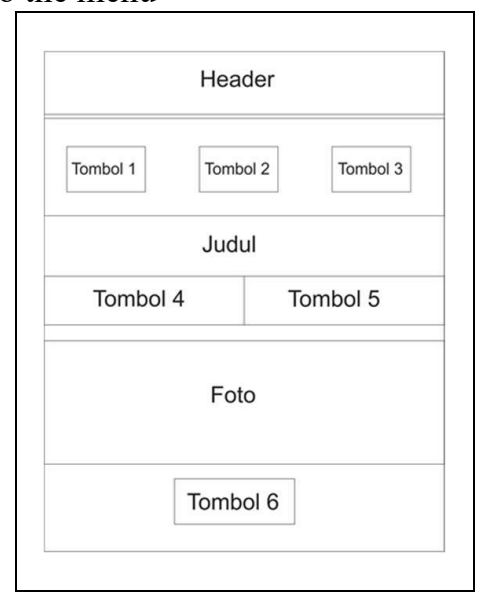

Fig. 7. Interface Menu Main Menu

Image component figure 7 :
a. Header
$=$ "Menu"
b. $1,2,3,4,5$ button $=$ Button to content
c. Title
$=$ Menu type
d. Button 6
$=$ Button to the initial interface

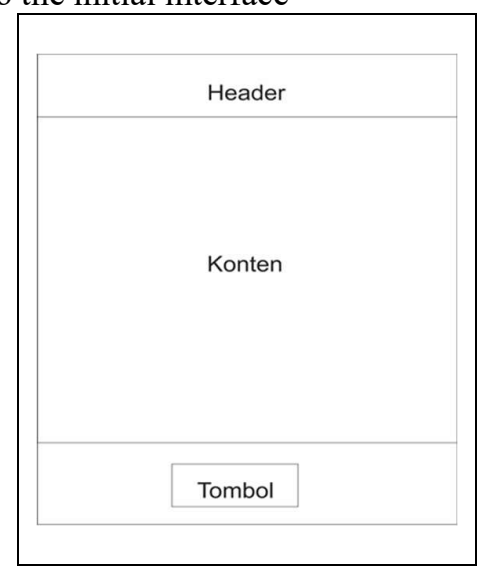

Fig. 8. Application content interface

Component Figure 8:
a. Header
$=$ "Menu"
b. $1,2,3,4,5$ button $=$ Button to content
c. Title
$=$ Menu type
d. Button 6
$=$ Button to the initial interface 


\subsubsection{Display of Android Device Distribution Capil}

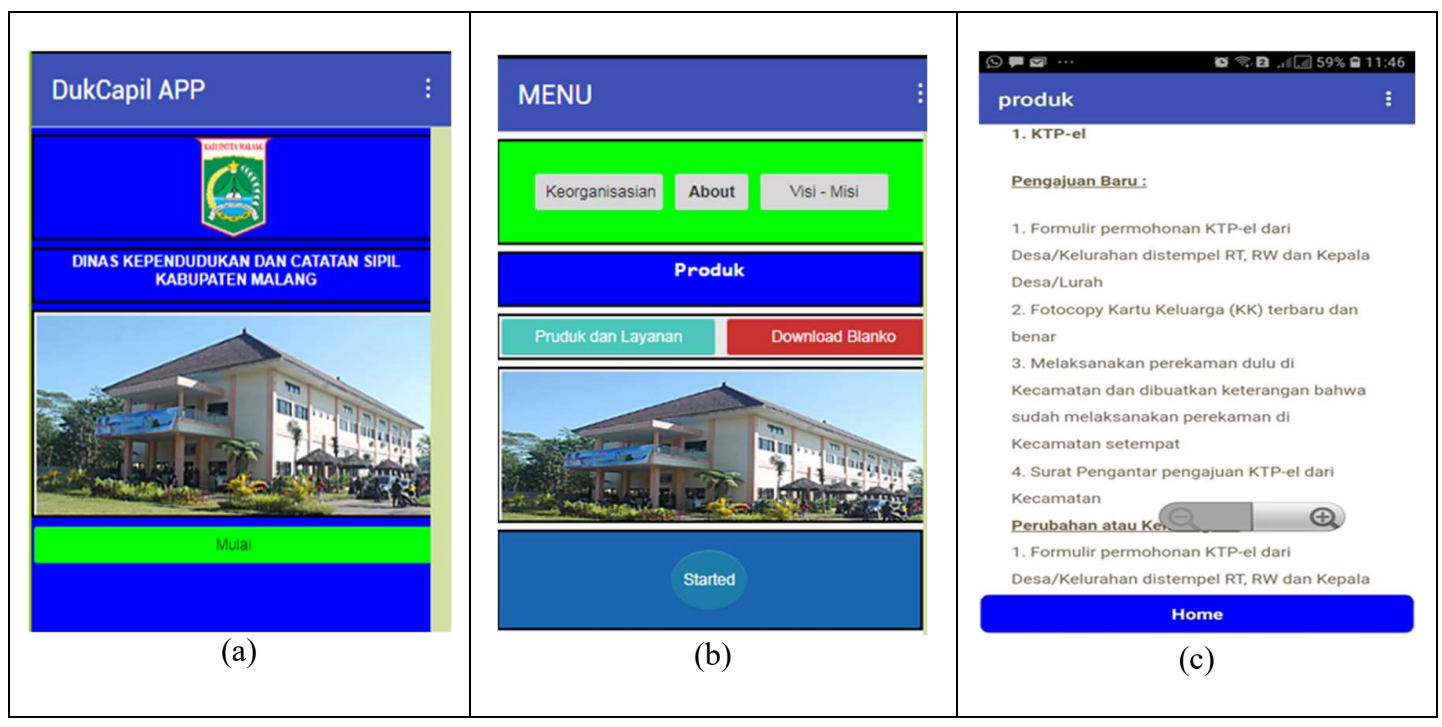

Fig. 9. (a) Initial views of Capil Dispendment Application, (b) Capil Dispenduk Application Menu Display,

(c) Display Dispenduk Capil content application page

\section{Conclusions}

From the results of research conducted, the authors can draw the following conclusions:

a. The Android-based Capil Dispenduk application has been successfully built, used as a public information medium.

b. The Android-based Capil Dispenduk application can meet the criteria in functional testing of the Android operating system.

c. Content is in accordance with the needs of the community.

[1] R. McLeod Jr and G. P. Schell, "Sistem Informasi Manajemen Edisi 10," Jakarta: Salemba Empat, 2008.

[2] C. J. L. Gaol, Sistem Informasi Manajemen. Grasindo, 2008.

[3] G. Lauren and M. Murtiwiyati, "Rancang Bangun Aplikasi Pembelajaran Budaya Indonesia Untuk Anak Sekolah Dasar Berbasis Android,” J. Ilm. KOMPUTASI, vol. 12, no. 2, pp. 1-10, 2019.

[4] K. Kusrini, “Aplikasi Sistem Pendukung Keputusan,” Yogyakarta Andi, 2007.

[5] J. HM, "Analisis dan Desain Sistem Informasi: Pendekatan Terstruktur dan Praktek Aplikasi Bisnis." Cetakan Kedua. Andi Offset. Yogyakarta, 1999.

[6] F. Wahyudi and S. Utama, "Sistem Pendukung Keputusan Penerimaan Dosen Baru Menggunakan Metode Profile Matching (Studi Kasus: Universitas Islam Raden Rahmat Malang)," G-Tech J. Teknol. Terap., vol. 3, no. 1, pp. 1-7, 2019. 